\title{
Identifying critical areas and habitat preferences of bottlenose dolphins Tursiops truncatus
}

\author{
Simon N. Ingram*, Emer Rogan \\ Aquaculture Development Centre, Department of Zoology and Animal Ecology, Environmental Research Institute, \\ University College Cork, Lee Maltings, Prospect Row, Cork, Ireland
}

\begin{abstract}
We present the findings of a 2-yr study of habitat use by bottlenose dolphins in the outer Shannon estuary on the west coast of Ireland. Data were collected during repeated, standardised, boat-based surveys of dolphins in a predefined $150 \mathrm{~km}^{2}$ area of the outer estuary. Areas found to exceed a uniform-use pattern were termed 'critical areas' and delimited using the $50 \%$ contour derived from harmonic mean transformation of sighting locations. Dolphins exhibited preferential use of areas of the estuary with the greatest benthic slope and depth, highlighting the influence of environmental heterogeneity on habitat use by this species. Additionally, photo-identification was used to catalogue sightings of uniquely marked dolphins which provided distribution data at an individual level. Although the ranges of frequently sighted dolphins overlapped, a degree of partitioning was found in the use of up-river parts of the study area. The methods presented here could be applied at a range of spatial scales and we suggest that the identification of critical areas within a population's range is a priority when planning any conservation management strategy for marine mammals.
\end{abstract}

KEY WORDS: Bottlenose dolphins $\cdot$ Habitat use $\cdot$ Critical areas $\cdot$ Conservation Resale or republication not permitted without written consent of the publisher

\section{INTRODUCTION}

Throughout their global range, bottlenose dolphins are commonly found in shallow, coastal habitats (Leatherwood \& Reeves 1983a). In this respect, the Shannon estuary on the west coast of Ireland represents a typical bottlenose dolphin habitat, and anecdotal records of their presence date back to 1835 (Knott 1997). Using mark-recapture analysis, the abundance of bottlenose dolphins using the Shannon estuary has been estimated at $113 \pm 16$ (SE) animals (Ingram 2000), and their regular use of the outer estuary, in particular, has been known since 1993 (Berrow et al. 1996). Living in close proximity to man exposes bottlenose dolphins to anthropogenic disturbance and potentially to the degradation of their habitat (Moscrop 1993).

Bottlenose dolphins in Irish waters are afforded protection by the 1976 Irish Wildlife Act (Rogan \& Berrow 1995) and are included in Annex II of the EU Habitats

\footnotetext{
*Email: s.ingram@ucc.ie
}

Directive as a species whose habitat requires special measures of protection with the designation of Special Areas of Conservation (SACs). In compliance, the Shannon estuary has recently been proposed as a 'candidate Special Area of Conservation' (cSAC) in order to protect resident bottlenose dolphins. Clearly, in order to plan and manage the conservation of this population under the Habitats Directive, knowledge of habitat use within the population's range is essential.

The concept of 'home-range' can be defined as 'that area traversed by the individual in its normal activities of food gathering, mating, and caring for young' (Burt 1943), and has been useful in the study of many terrestrial mammal species (Jewell 1966). In general, homerange size has been shown to be larger for carnivores than herbivores and directly proportional to body mass in terrestrial mammals (McNab 1963, Harestad \& Bunnell 1979, Garland 1983, Lindstedt et al. 1986). More recently this concept has also been applied to the movements and habitat use of marine mammals (see for example, Irvine et al. 1981, Shane et al. 1986, Bal- 
lance 1992, Thompson et al. 1996, Wilson et al. 1997, Tollit et al. 1998). Bottlenose dolphins are top marine predators and efficient swimmers, and therefore might be expected to have large home ranges. Indeed, a marked increase in the abundance of dolphins using the estuary between May and September (Ingram 2000) indicates that the Shannon estuary does not represent the whole of this population's range.

Non-uniform use of habitat has been demonstrated amongst several species of terrestrial mammal with distinct core areas within individuals' home-ranges (Gates 1979, Duncan 1983, Samuel et al. 1985). Environmental heterogeneity has also been shown to influence habitat use by marine mammals. For example, factors such as water temperature, depth, sea-bed gradient and sediment type have been shown to influence the distribution of several cetacean and pinniped species (Gaskin 1968, Kenney 1990, Baumgartner 1997, Tollit et al. 1998, Guinet et al. 2001). Bottlenose dolphins are found in a wide variety of habitats, and habitat use by resident populations differs between locations. For example, bottlenose dolphins in the Moray Firth, Scotland prefer deeper areas with steep benthic topography (Wilson et al. 1997), whereas dolphins resident in Florida favour shallow areas of $<3 \mathrm{~m}$ depth (Irvine et al. 1981). Clearly it is necessary to study and understand habitat use on a site-specific basis before making recommendations regarding habitat management.
We surveyed the outer Shannon estuary repeatedly throughout the present study and used the locations of encountered dolphin schools to identify areas of high relative use. We define these areas as 'critical areas' and consider them of fundamental importance to dolphins using the estuary. In addition, we examined the use of areas with different water depths and benthic slopes and identified the depth and sea-bed gradients most frequently used by dolphins in order to examine the potential influence of benthic topography on dolphin distribution. Finally, in order to investigate habitat use at an individual level, we used photoidentification to examine the ranging patterns of individual animals.

\section{MATERIALS AND METHODS}

Study area. The Shannon is the longest river in the British Isles and meets the Atlantic at $52^{\circ} \mathrm{N}$ and $10^{\circ} \mathrm{W}$ on Ireland's west coast, $250 \mathrm{~km}$ from its source (Fig. 1). The river meets the sea via a $75 \mathrm{~km}$ tidal estuary with a $5 \mathrm{~m}$ vertical tidal range during spring tides (Anonymous 1997) and currents in excess of $2.5 \mathrm{~m} \mathrm{~s}^{-1}$ in the narrows (pers. obs.). The Shannon estuary is a major shipping route and is used to transport over 10 million tonnes of shipping annually, including the largest ships entering Irish waters (180000 t) (Anonymous 1997). In addition to industrial shipping, growth in

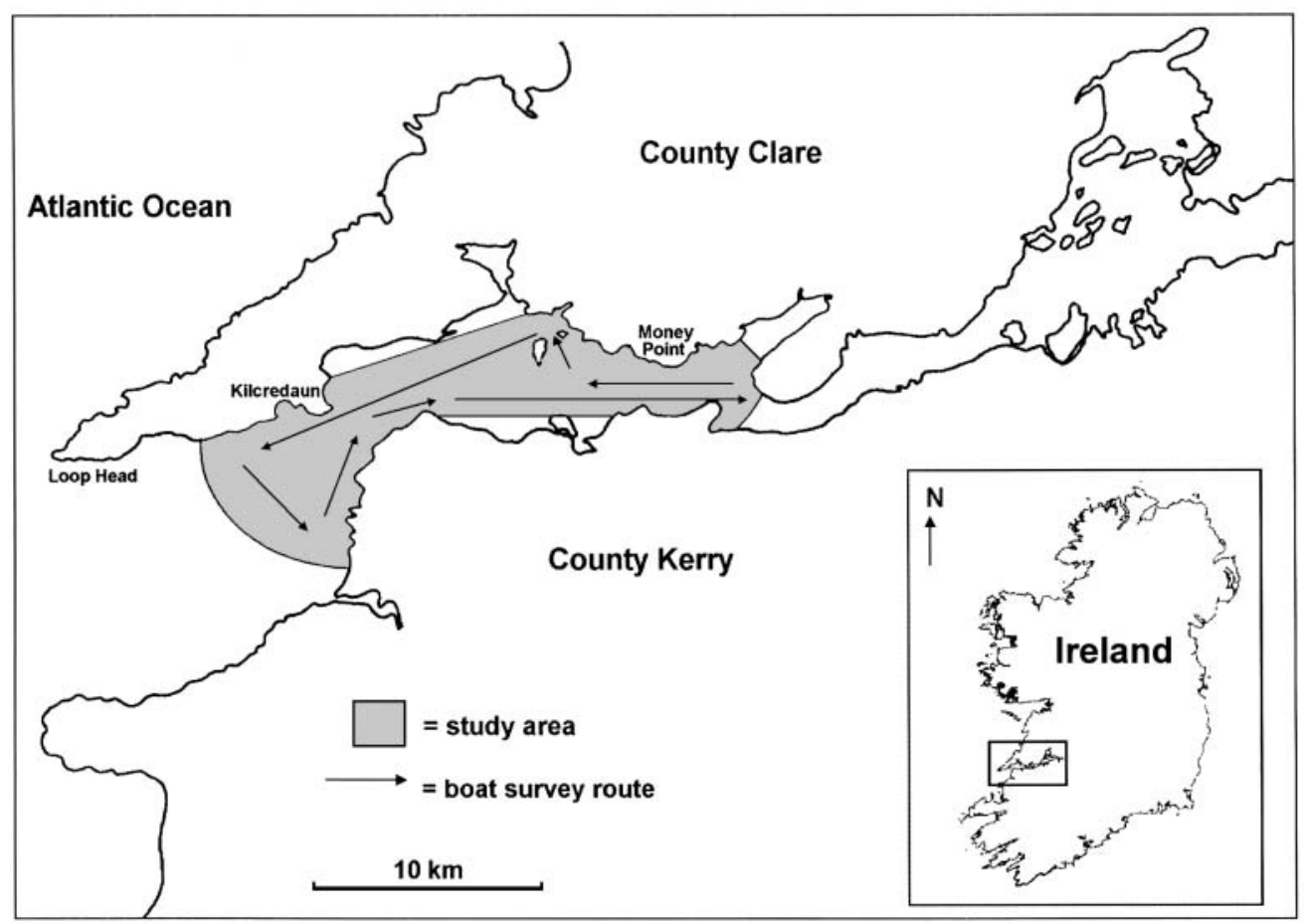

Fig. 1. Outer Shannon estuary, showing the $150 \mathrm{~km}^{2}$ dolphin study area and principal locations referred to in the text 
tourism has resulted in a recent increase in leisure boat activity, in particular the growing dolphin-watching tourism which targets dolphins in the outer estuary (Berrow \& Holmes 1999).

Boat survey methods. Throughout the 25 mo study, we conducted standardised boat-based surveys in a $150 \mathrm{~km}^{2}$ area of the outer estuary (Fig. 1). The survey route was selected to cover an area known to be used by bottlenose dolphins (Berrow et al. 1996) and by local dolphin-watching boats. Surveys were conducted in Beaufort sea-states 3 or lower, and attempted twice a month between May and September and once a month the remainder of the year. To ensure the independence of data samples, when possible, surveys were not conducted on consecutive days. Surveys were conducted using a rigid inflatable boat (RIB) equipped with an $80 \mathrm{hp}$ 2-stroke, outboard engine. Surveys were conducted at a steady speed of approximately $20 \mathrm{~km} \mathrm{~h}^{-1}$ and a constant lookout for dolphins was maintained.

A dolphin school was defined as all dolphins within a $100 \mathrm{~m}$ radius of each other (from Irvine et al. 1981) and an interaction with a dolphin school is termed an 'encounter'. Once sighted, we approached dolphin schools slowly in order to minimise disturbance and recorded their positions $( \pm 100 \mathrm{~m})$ using a hand-held global positioning system (GPS). During each encounter attempts were made to photograph all members of the school. Slide photographs were taken using a $35 \mathrm{~mm}$ autofocus camera (Canon EOS 50) with a Canon 75-300 mm (f4-5.6) telephoto zoom lens. Encounters continued until all the animals in the school had been photographed or until $10 \mathrm{~min}$ had elapsed without a sighting. The survey was then resumed until the route was completed or another dolphin school was encountered. The outward and return legs of the survey were spaced at least $1 \mathrm{~km}$ apart to avoid resampling the same areas within a single survey. Surveys on which the route was completed were classed as 'full', and surveys which were abandoned due to deteriorating weather were classed as 'part'.

Photographic identification of individuals. Photoidentification of bottlenose dolphins relies on matching marks and nicks on their dorsal fins and flanks (Würsig \& Würsig 1979, Würsig \& Jefferson 1990, Wilson et al. 1999). The trailing edge of the dorsal fin, in particular, is easily damaged, resulting in a unique dorsal fin profile. The photographic slides taken during surveys were examined on a lightbox using an $8 \times$ loupe magnifier. The best photographs taken of every dolphin in each encounter were selected and matched with a catalogue of identified individuals. Identifications and details relating to school membership, such as encounter location and school code, were recorded on a database from which individual sighting histories could be reconstructed. If a match was not found, the individual was given a unique identification number and added to the catalogue.

Areal analysis. Relative use of water depth and slope categories: We divided the survey area into $1 \mathrm{~km}^{2}$ cells according to the Ordnance Survey of Ireland (OSI) grid and derived depth and slope data using the relevant Admiralty charts (\#1548, \#1547 and \#1819). In this way, we assigned each cell in the study area to 1 of 5 categories of maximum depth: 0-10, 11-20, 21-30, 31-40, and $>40 \mathrm{~m}$ (Fig. 2a). We also calculated the maximum difference in charted depths within each cell (maxi-
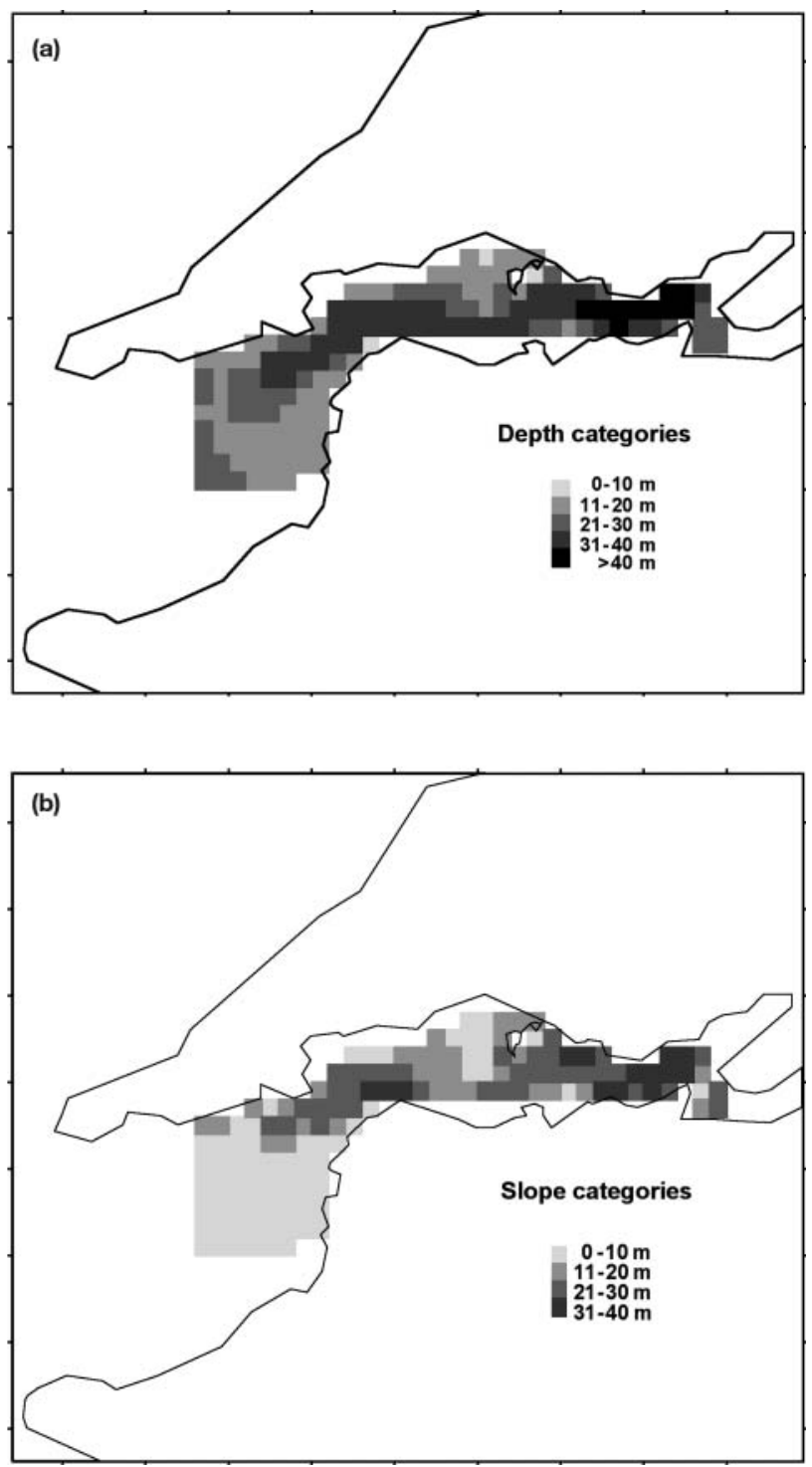

Fig. 2. (a) Bathymetry of each $1 \mathrm{~km}^{2}$ Ordnance Survey of Ireland (OSI) cell within the survey area; (b) Degree of slope within each $1 \mathrm{~km}^{2}$ OSI cell within the outer Shannon survey area. Slope is calculated as the maximum difference in charted depth within each cell 
mum depth minus minimum depth) as an indication of benthic slope and assigned them to the following categories, 0-10, 11-20, 21-30, and 31-40 m (Fig. 2b).

We calculated the relative survey effort in each category of depth and slope using GPS track data available from 18 boat surveys as follows:

$$
A_{i}=\frac{\sum_{j} S_{i j}}{\sum_{i} \sum_{j} S_{i j}}
$$

where $A_{i}$ represents the relative availability of depth or slope category $i$, and $S_{i j}$ represents the number of times cell $j$ with slope or depth category $i$ was investigated. In this way, only cells entered during surveys were included in subsequent analysis, and the availability of each category of depth and slope was calculated according to search effort. The positions of all sightings of dolphin schools from all boat surveys were then plotted and the relative use of each category of depth and slope was calculated as follows:

$$
U_{i}=\frac{\sum_{j} n_{i j}}{\sum_{i} \sum_{j} n_{i j}}
$$

where $U_{i}$ represents the relative use of depth or slope category $i$ and $n_{i j}$ is the number of encounters with dolphins in cell $j$ of depth or slope category $i$.

A simple index of preference (Hunter 1962) for each depth and slope category was then calculated as follows:

$$
P_{i}=\frac{U_{i}}{A_{i}}
$$

where $P_{i}$ is the index of preference for category $i, U_{i}$ represents the use of category $i$, calculated from the

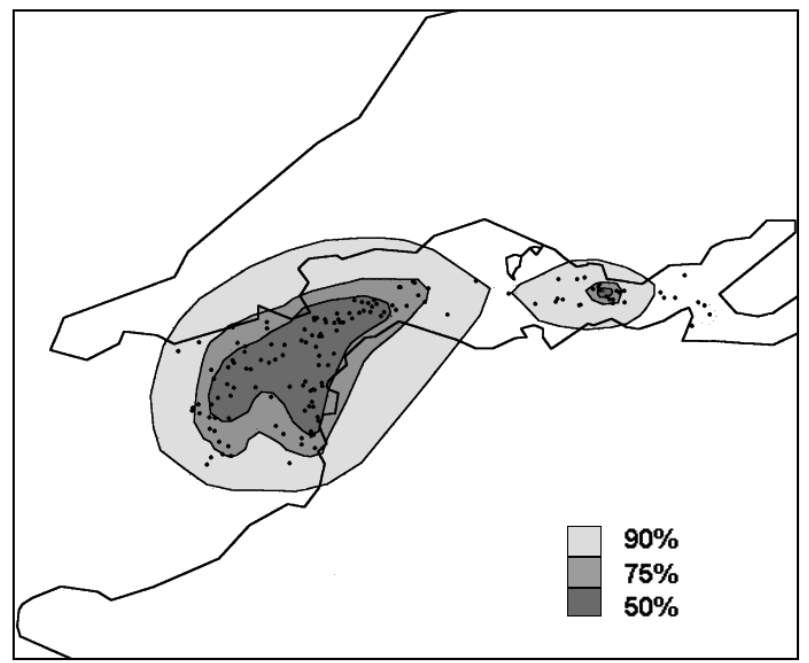

Fig. 3. Tursiops truncatus. Distribution of sightings within the outer Shannon estuary survey area from all surveys. Each encounter location is denoted by a point $(n=150)$. Contours are plotted to show the location of 50, 75 and $90 \%$ harmonic mean isopleths distribution of sightings data and $A_{i}$ is the relative availability of category $i$, as described above. Thus, $P_{i}=$ 0 indicates total avoidance of a category, $P_{i}<1$ indicates avoidance, and $P_{i}>1$ shows preferential use of a category.

We then compared the relative frequency of sightings of dolphins in the different depth and slope categories with values expected from a uniform distribution of sightings using a chi-square test.

Identification of critical areas: Using the homerange analysis software Calhome (Kie et al. 1994), harmonic mean analysis, a non-parametric gridding procedure (Dixon \& Chapman 1980), was used to plot contours according to isopleths of habitat use.

Areas of high relative use were identified by examining the frequency of sightings within each $1 \mathrm{~km}^{2}$ cell within the $90 \%$ harmonic isopleth (Samuel et al. 1985). All cells were ordered according to use and the resulting cumulative distribution function (CDF) was compared with values derived from a hypothetical uniform distribution. Critical areas were identified as areas within the appropriate isopleth that included all cells with a higher than expected sighting frequency.

Known ranges of identified dolphins and use of critical areas: Because data relating to the movements of dolphins during this study are restricted to the Shannon estuary, calculations of ranges of individual dolphins are treated here as 'known-ranges' rather than complete 'home-ranges'.

Minimum convex polygon (MCP) areas were calculated for each dolphin sighted in more than 10 encounters. We then examined the increase in area of the resulting MCPs with the increase in the number of sightings of each animal. The use of the critical areas by identified individuals was then investigated by examining the known ranges of these frequently sighted dolphins.

\section{RESULTS}

In total, 45 boat-based surveys were conducted during the study, of which 32 were 'full' surveys and 13 were 'part' surveys. Altogether, 162 dolphin schools were encountered during surveys with a median school size of 5 dolphins.

\section{Identifying critical areas}

Using harmonic mean transformation of encounter locations we plotted isopleths of dolphin distribution within the outer estuary (Fig. 3). We ordered 121 grid cells within the $90 \%$ harmonic isopleth according to encounter frequency and calculated the point of inter- 


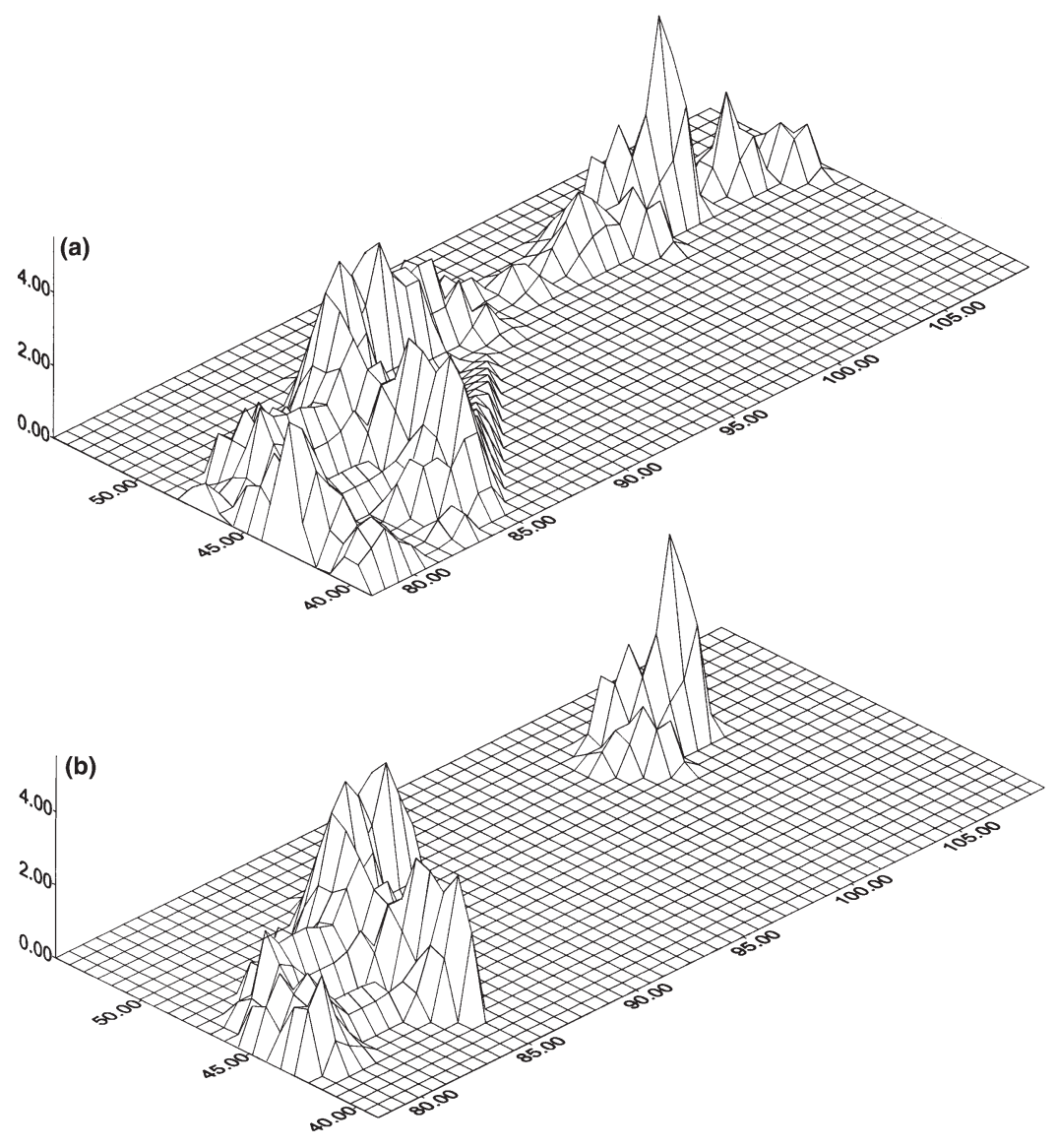

Fig. 4. Tursiops truncatus. Distribution of habitat utilization. $x$ - and $y$-axes show the OSI grid and the $z$-axis shows the number of sightings for each $1 \mathrm{~km}^{2}$ cell within the study area. (a) Dolphin encounters throughout the whole survey area; (b) dolphin encounters within the 2 critical areas, delimited by the $50 \%$ harmonic mean isopleth shown in Fig. 3 classes $0-10,11-20$, and 21-30 m (p < 1) and preferential use of depth classes 31-40 and 41-50 $\mathrm{m} \mathrm{(p} \mathrm{>} \mathrm{1).} \mathrm{Cells} \mathrm{with}$ slope categories of $0-10$ and $11-20 \mathrm{~m}$ showed low relative use, whereas areas with slopes of 31-40 m showed high relative use $(p>1)$. The distribution of sightings was non-uniform with respect to depth $\left(\chi^{2}=20.56\right.$, df $\left.=4, \mathrm{p}<0.001\right)$ and slope $\left(\chi^{2}=8.01\right.$, df $\left.=3, p<0.05\right)$.

\section{Known-ranges of individual dolphins}

Twelve dolphins were encountered on more than 10 occasions with a maximum of 16 sightings for 2 animals (Table 1). The MCP areas of known ranges of these commonly sighted individuals differed in size and location. For example, Dolphin 70 used $50 \%$ of the survey area and Dolphin 197 was only sighted in the up-river part of the study area (Fig. 6). The MCP area for 6 of these animals (i.d. catalogue numbers; $25,29,37,72,244$ and 286) reached an asymptote after approximately 8 sightings, but no asymptote was reached for the MCPs of the remaining 6 dolphins (Fig. 7). All 44 animals sighted 5 or more times used 1 or both of the 2 critical areas. Forty-two $(95 \%)$ had ranges that extended into or across the western critical area (Fig. 8) and 15 animals (34\%) had ranges that included the smaller eastern critical area. Thirteen dolphins (30\%) used both of these areas. section with a hypothetical uniform distribution (after Samuel et al. 1985). The observed and the expected cumulative distribution functions differed significantly (Kolmogorov D+, p < 0.001, $\mathrm{n}=139$ ) showing a nonuniform distribution of encounters. The $50 \%$ harmonic isopleth was identified as the boundary for 2 critical areas since it parsimoniously covered all cells of significantly high use (Fig. 4). The 2 critical areas were located in deep parts of the estuary with fast tidal currents.

\section{Influence of benthic topography on dolphin distribution}

Dolphins were found to use deeper areas of the estuary with steep sloping benthic topography more than shallower areas with lower benthic gradients (Fig. 5). Dolphins showed low relative use of depth

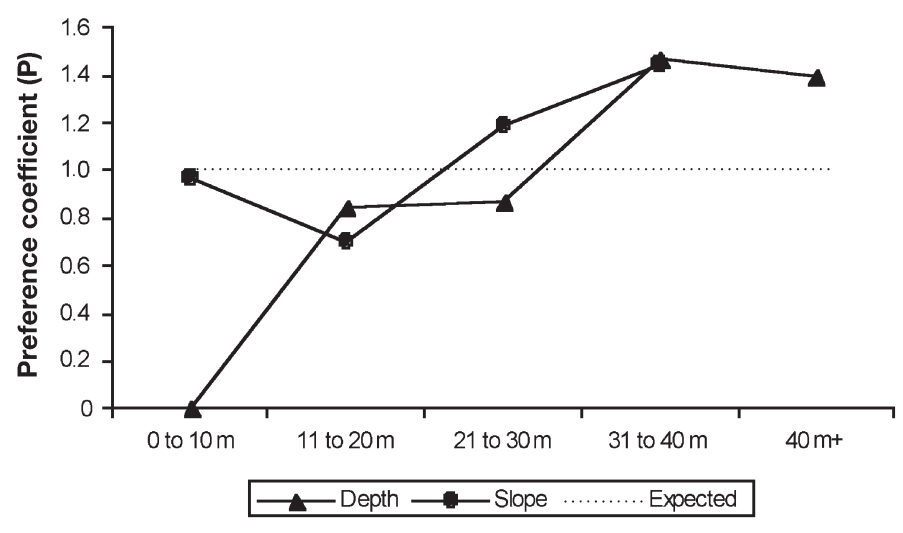

Fig. 5. Tursiops truncatus. Preference by bottlenose dolphins for habitat with different depth and slope categories. A $\mathrm{p}$-value of zero indicates total avoidance of a category, values below 1 indicate avoidance, and values above 1 show preferential use of a category 
Table 1. Tursiops truncatus. Summary of the known ranges of 12 adult bottlenose dolphins sighted on at least 10 occasions. Distances for extremes in the range of individuals are given as $\mathrm{km}$ east of Loop Head at the mouth of the estuary. MCP: minimum area convex polygon

\begin{tabular}{|lclcc|}
\hline $\begin{array}{l}\text { Dolphin } \\
\text { number }\end{array}$ & $\begin{array}{c}\text { No. of } \\
\text { sightings }\end{array}$ & $\begin{array}{l}\text { MCP } \\
\left(\mathrm{km}^{2}\right)\end{array}$ & $\begin{array}{c}\text { Max. west } \\
(\mathrm{km})\end{array}$ & $\begin{array}{c}\text { Max. east } \\
(\mathrm{km})\end{array}$ \\
\hline 25 & 14 & 35.33 & 10.7 & 26.4 \\
29 & 12 & 49.67 & 8.6 & 21.8 \\
37 & 16 & 58.72 & 10.6 & 21.8 \\
61 & 15 & 51.08 & 11.0 & 37.4 \\
70 & 14 & 64.9 & 14.9 & 37.4 \\
72 & 12 & 37.34 & 9.5 & 21.8 \\
73 & 16 & 46.4 & 14.5 & 40.0 \\
109 & 14 & 53.4 & 10.7 & 37.4 \\
155 & 15 & 75.5 & 14.1 & 39.6 \\
197 & 12 & 19.2 & 22.7 & 40.0 \\
244 & 12 & 45.01 & 8.6 & 18.5 \\
286 & 11 & 36.1 & 7.5 & 18.5 \\
\hline
\end{tabular}

\section{DISCUSSION}

Dolphins were encountered throughout the survey area but the distribution of dolphin encounters was non-uniform within the outer Shannon estuary. We defined 2 distinct critical areas bordered by $50 \%$ harmonic isopleths and consider these highuse areas of fundamental importance to bottlenose dolphins using the estuary.

'Patchiness' in the distribution of terrestrial mammals has been linked to the heterogeneity of their habitat (Gates 1979, Duncan 1983, Samuel et al. 1985), and dolphins in the Shannon showed preferential use of habitat areas with greatest depth and slope. The preferential use of areas with steep benthic topography have been shown in studies of other cetacean populations (see for example, Baumgartner 1997, Wilson et al. 1997). Bottlenose dolphins prey on a wide variety of fish, cephalopod and crustacean species (Barros \& Odell 1990, Cockroft \& Ross 1990) using a variety of prey capture techniques (see Leatherwood 1975, dos Santos \& Lacerda 1987, Shane 1990, Bel'kovich 1991), and steeply sloping benthic topography may provide high concentrations of prey fish or aid the dolphins in their foraging activities (Ballance 1992, Wilson et al. 1997).

Results of dedicated shore-based observations of dolphin schools, using the outer of the 2 critical areas, have shown the importance of this area for foraging related activities (Ingram 2000). Furthermore, the activity of dolphin schools in this critical area was found to be significantly affected by the tidal cycle, with schools being over twice as likely to be foraging during flowing tidal states than during slack water. During boat surveys, dolphins were seen throwing several fish species during foraging bouts, including salmon Salmo salar, garfish Belone belone and eels Anguilla anguilla, and the importance of the Shannon as a salmon river in particular may be fundamental to the use of the estuary by bottlenose dolphins (Ingram 2000).

The incorporation of passive acoustic techniques into future research may provide important information regarding subsurface activity and the use of the water column by foraging dolphins in these critical areas (Hastie 2000, Janik 2000). In addition, detailed surveys of prey distribution and movements in these critical areas would consolidate data relating to dolphin movements and behaviour (see for example Allen et al. 2001).

Bottlenose dolphins tend to aggregate around the entrances to estuaries, lagoons and bays (Würsig 1978,

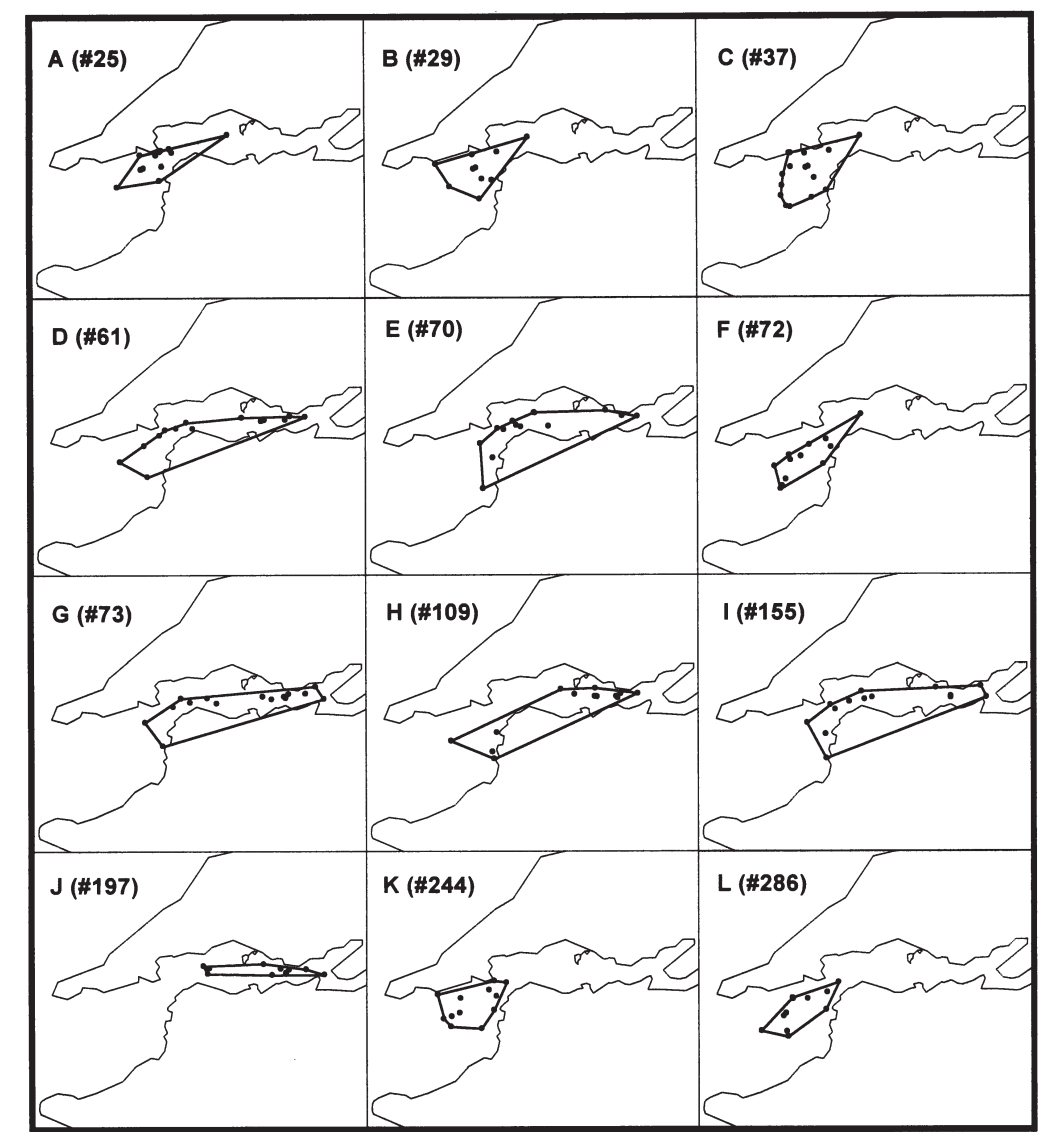

Fig. 6. Tursiops truncatus. Minimum convex polygons for dolphins sighted over more than 10 encounters. Figures in brackets are dolphins' photo-i.d. catalogue numbers 

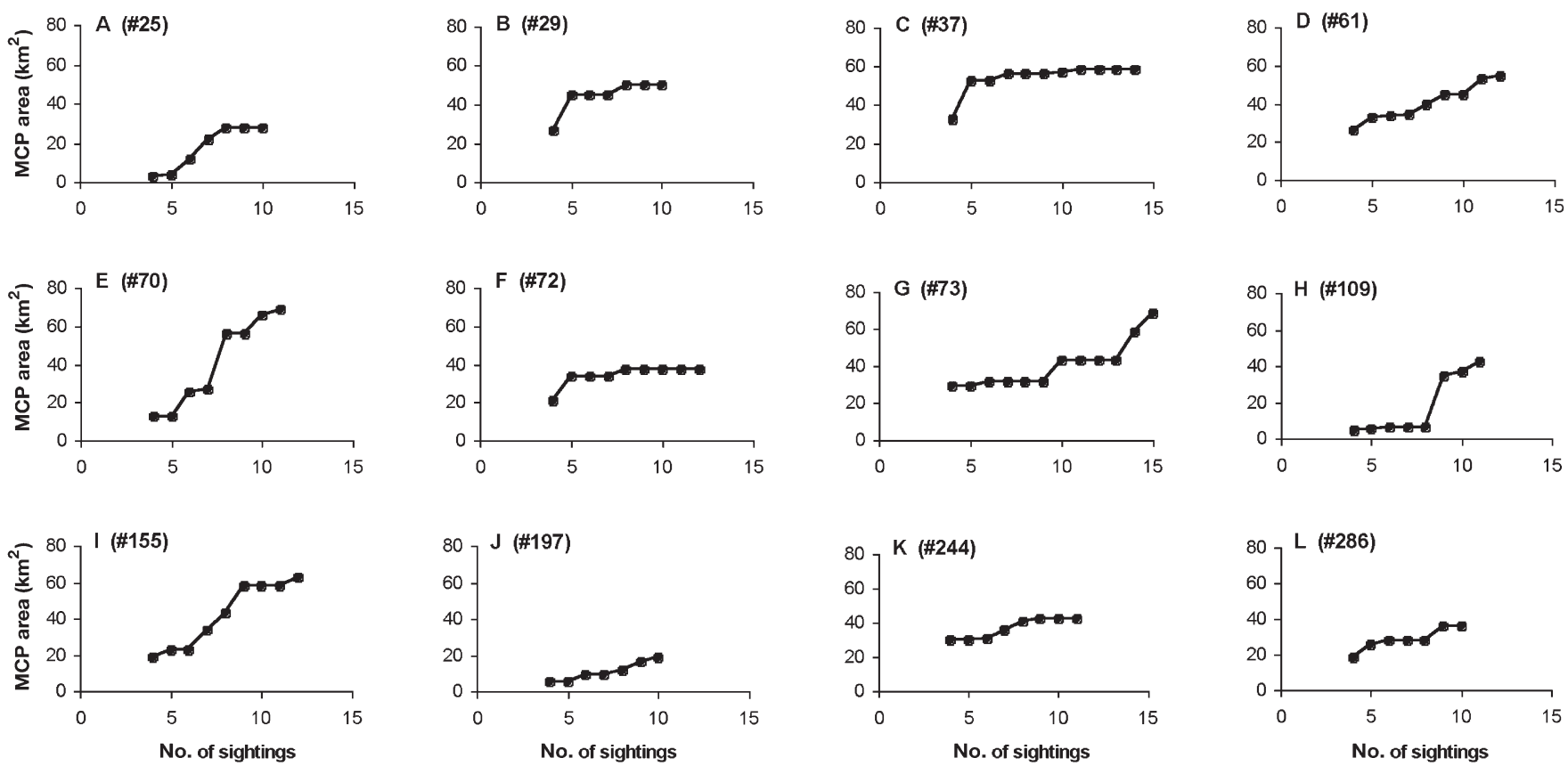

Fig. 7. Tursiops truncatus. Plots of minimum convex polygon (MCP) area with increasing numbers of re-sightings for each dolphin sighted on 10 or more surveys. Sighting locations are from different surveys, figures in brackets are dolphins' photo-i.d. catalogue numbers

Leatherwood \& Reeves 1983b, dos Santos \& Lacerda 1987, Ballance 1992, Fertl 1994, Wilson et al. 1997), often concentrating in areas of fast tidal current (Irvine et al. 1981, Shane 1980 \& 1990, Harzen 1998), and it appears in this respect that the outer Shannon estuary represents a typical bottlenose dolphin habitat.

By examining the MCPs of identified dolphins, our results indicate a degree of resource partitioning within the estuary. Some members of the population are frequently encountered up-river, whereas sightings of the majority of the population are concentrated at the estuary mouth.

There are limitations associated with cetacean conservation measures relying on habitat protection. Specifically, cetaceans do not occupy and return regularly to a home space

Fig. 8. Tursiops truncatus. Extremes in longitudinal range of sightings of each animal encountered on 5 or more occasions. Distances are km east of Loop Head at the mouth of the estuary. There are no sightings recorded within $10 \mathrm{~km}$ of the estuary mouth since this area lies beyond the survey area. The dashed lines mark the boundaries of both critical areas

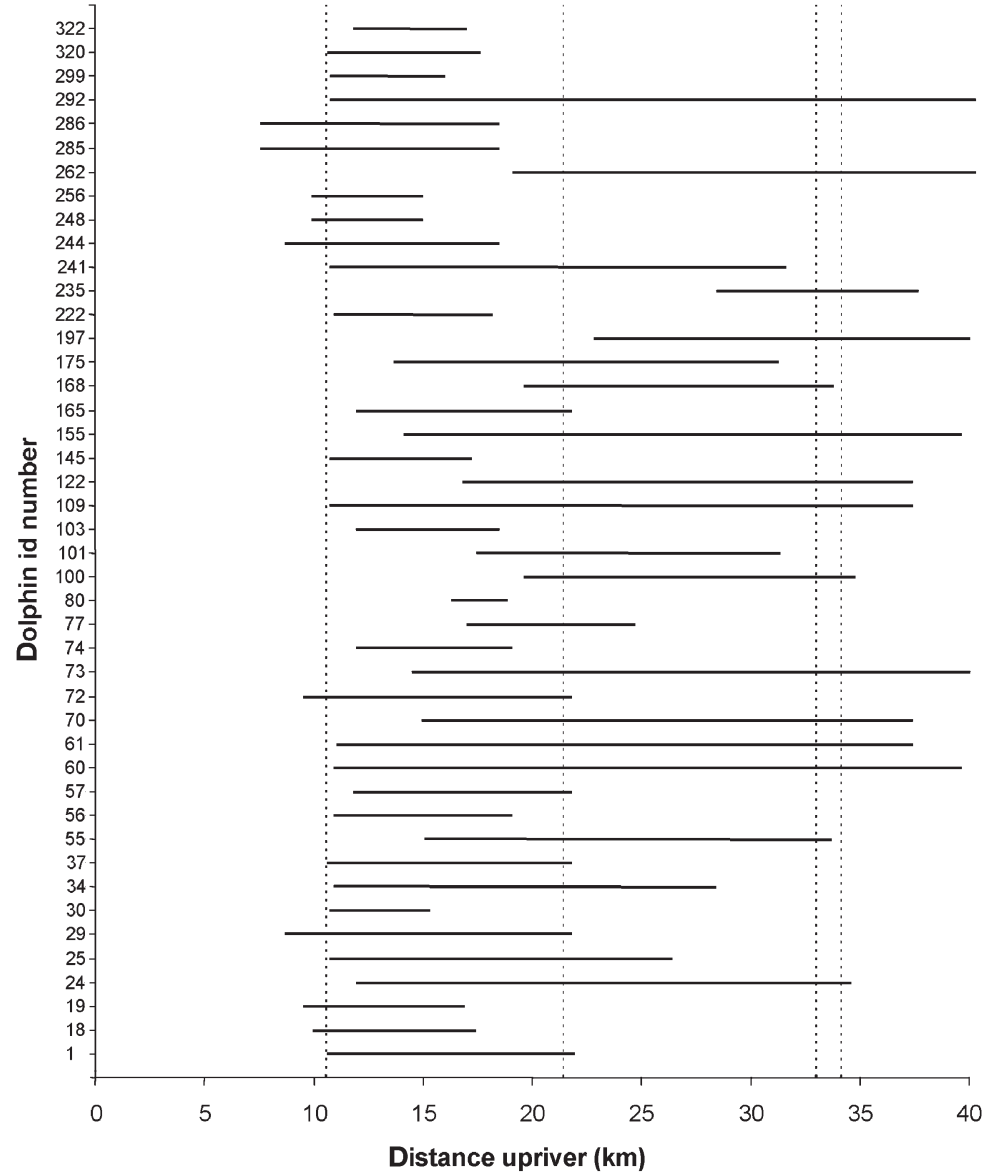


and instead tend to be highly mobile, and capable of travelling great distances in a short period (Wilson et al. 1997). Many cetacean species are migratory and seasonal changes in abundance of bottlenose dolphins in the Shannon (Ingram 2000) indicates at least a small-scale seasonal migration of this population.

The Shannon is clearly an important habitat area for bottlenose dolphins but the estuary does not include the full geographical range of this population. By extending the range of future surveys, knowledge of the movements of bottlenose dolphins in adjacent waters, identified from the Shannon, would contribute greatly to the conservation needs of this population.

The different ranging patterns of individuals within the dolphin population should also have consequences for habitat-management decision making. Specifically, fewer dolphins utilise the upriver critical area of the estuary and impacts from dolphin-watching tourism and other industries in these parts of the SAC will be borne by fewer individuals than similar activities near the estuary mouth.

Acknowledgements. This project was funded under the Irish Marine Institute's Marine Research Measure programme (IR.95.MR.007), with an additional financial contribution from Dúchas, The Irish Heritage Service. We would like to thank the Aquaculture Development Centre UCC and all those who kindly gave up their time to help with our fieldwork especially Mick Mackey and Trish Clayton. We would also like to thank Geoff and Sue Magee for sharing their knowledge of the Shannon dolphins, and their hospitality. We are grateful to Bord Iascaigh Mhara (BIM) for loan of a Tornado RIB and to Kilrush Creek Marina and Boatyard for the use of their facilities. Thanks also to Dave Barnes, Tom Kelly, Paddy Sleeman, Paul Thompson, Ben Wilson and 3 anonymous referees for their helpful comments on earlier drafts of this manuscript. We would also like to acknowledge our project partners, The Irish Whale and Dolphin Group and The Hydraulics and Maritime Research Centre, University College Cork.

\section{LITERATURE CITED}

Allen MC, Read AJ, Gaudet J (2001) Fine-scale habitat selection of foraging bottlenose dolphins Tursiops truncatus near Clearwater, Florida. Mar Ecol Prog Ser 222:253-264

Anonymous (1997) Shannon estuary tide tables. Shannon Estuary Ports, Limerick

Ballance LT (1992) Habitat use patterns and ranges of the Bottlenose Dolphin in the Gulf of California, Mexico. Mar Mamm Sci 8(3):262-274

Barros NB, Odell DK (1990) Food habits of bottlenose dolphins in the southeastern United States. In: Leatherwood $\mathrm{S}$, Reeves RR (eds) The bottlenose dolphin. Academic Press, San Diego, p 309-328

Baumgartner MF (1997) The distribution of Risso's dolphin (Grampus griseus) with respect to the physiography of the northern gulf of Mexico. Mar Mamm Sci 13(4):614-638

Bel'kovichVM (1991) Herd structure, hunting, and play; bottlenose dolphins in the Black Sea. In: Pryor K, Norris
KS (eds) Dolphin societies; discoveries and puzzles. University of California Press, Berkeley, p 17-77

Berrow SD, Holmes B (1999) Tour boats and dolphins: a note on quantifying the activities of whalewatching boats in the Shannon estuary, Ireland. J Cetacean Res Manag 1(2): 199-204

Berrow SD, Holmes B, Kiely OR (1996) Distribution and abundance of bottle-nosed dolphins Tursiops truncatus (Montagu) in the Shannon estuary. Biol Environ 96B(1):1-9

Burt WH (1943) Territoriality and home range concepts as applied to mammals. J Mammal 24:346-352

Cockroft VG, Ross GJB (1990) Food and feeding of the Indian Ocean bottlenose dolphin off southern Natal, South Africa. In: Leatherwood S, Reeves RR (eds) The bottlenose dolphin. Academic Press, San Diego, p 295-308

Dixon KR, Chapman JA (1980) Harmonic mean measure of animal activity areas. Ecology 61(5):1040-1044

dos Santos ME, Lacerda M (1987) Preliminary observations of the bottlenose dolphin (Tursiops truncatus) in the Sado estuary (Portugal). Aquat Mamm 13(2):65-80

Duncan P (1983) Determinants of the use of habitat by horses in a Mediterranean wetland. J Anim Ecol 52:93-109

Fertl D (1994) Occurrence patterns and behavior of bottlenose dolphins (Tursiops truncatus) in the Galveston ship channel, Texas. Tex J Sci 46(4):299-317

Garland T (1983) Scaling the ecological cost of transport to body mass in terrestrial mammals. Am Nat 121(4):571-587

Gaskin DE (1968) Distribution of Delphinidae (Cetacea) in relation to sea surface temperatures off eastern and southern New Zealand. NZ J Mar Freshw 2:527-534

Gates S (1979) A study of home ranges of free-ranging Exmoor ponies. Mamm Rev 9(1):3-18

Guinet C, Dubroca L, Lea MA, Goldsworthy S, Cherel Y, Duhamel G, Bonadonna F, Donnay JP (2001) Spatial distribution of foraging in female Antarctic fur seals Arctocephalus gazella in relation to oceanographic variables: a scale-dependent approach using geographical information systems. Mar Ecol Prog Ser 219:251-264

Harestad AS, Bunnell FL (1979) Home range and body weight - a re-evaluation. Ecology 60(2):389-402

Harzen S (1998) Habitat use by the bottlenose dolphin (Tursiops truncatus) in the Sado estuary, Portugal. Aquat Mamm 24(3):117-128

Hastie GD (2000) Fine-scale aspects of habitat use and behaviour by bottlenose dolphins (Tursiops truncatus). $\mathrm{PhD}$ thesis, University of Aberdeen

Hunter RF (1962) Hill sheep and their pasture, a study of sheep grazing in South East Scotland. J Ecol 50:651-680

Ingram SN (2000) The ecology and conservation of bottlenose dolphins in the Shannon estuary, Ireland. PhD thesis, University College Cork, Ireland

Irvine AB, Scott MD, Wells RS, Kaufmann JH (1981) Movements and activities of the Atlantic bottlenose dolphin, Tursiops truncatus, near Sarasota, Florida. Fish Bull 79(4): 671-688

Janik VM (2000) Food-related bray calls in wild bottlenose dolphins (Tursiops truncatus) Proc R Soc Lond B 267: 923-927

Jewell PA (1966) The concept of home range in mammals. Symp Zool Soc Lond 18:85-109

Kenney RD (1990) Bottlenose dolphins off the north-eastern United States. In: Leatherwood S, Reeves RR (eds) The bottlenose dolphin. Academic Press, San Diego, p 369-386

Kie JG, Baldwin JA, Evans CJ (1994) Calhome: home range analysis program, electronic users manual. University of California, Fresno 
Knott MJ (1997) Two months in Kilkee. Clasp Press, Ennis Leatherwood S (1975) Some observations of feeding behavior of bottle-nosed dolphins (Tursiops truncatus) in the Northern Gulf of Mexico and (Tursiops cf. T. gilli) off Southern California, Baja California and Nayarit, Mexico. Mar Fish Rev 37(9):10-16

Leatherwood S, Reeves RR (1983a) The Sierra Club handbook of whales and dolphins. Sierra Club Books, San Francisco

Leatherwood S, Reeves RR (1983b) Abundance of Bottlenose Dolphins in Corpus Christi Bay and Coastal Southern Texas. Contrib Mar Sci 26:179-199

Lindstedt SL, Miller BJ, Buskirk SW (1986) Home range, time, and body size in mammals. Ecology 67(2):413-418

McNab BK (1963) Bioenergetics and the determination of home range size. Am Nat 97:133-140

Moscrop A (1993) An assessment of threats to marine cetaceans resulting from the degradation of their habitats. MSc thesis, University of Greenwich

Rogan E, Berrow SD (1995) The management of Irish waters as a whale and dolphin sanctuary. In: Blix AS, Walløe L, Ulltang $\varnothing$ (eds) Whales, seals, fish and man. Elsevier Science, Amsterdam, p 671-681

Samuel MD, Pierce DJ, Garton EO (1985) Identifying areas of concentrated use within the home range. J Anim Ecol 54: $711-719$

Shane SH (1980) Occurrence, movements and distribution of bottlenose dolphin, Tursiops truncatus, in Southern Texas. Fish Bull 78 (3):593-601

Shane SH (1990) Behavior and ecology of the bottlenose dolphin at Sanibel Island, Florida. In: Leatherwood S, Reeves

Editorial responsibility: Otto Kinne (Editor),

Oldendorf/Luhe, Germany
RR (eds) The bottlenose dolphin. Academic Press, San Diego, p 369-386

Shane SH, Wells RS, Würsig B (1986) Ecology, behavior and social organisation of the bottlenose dolphin:a review. Mar Mamm Sci 2(1):34-63

Thompson PM, McConnell BJ, Tollit DJ, Mackay A, Hunter C, Racey P (1996) Comparative distribution, movements and diet of harbour and grey seals from the Moray Firth, NE Scotland. J Appl Ecol 33:1527-1584

Tollit DJ, Black AD, Thompson PM, Mackay A, Corpe $H_{\text {, }}$ Wilson B, Van Parijs SM, Grellier K, Parlane S (1998) Variations in harbour seal Phoca vitulina diet and divedepths in relation to foraging habitat. J Zool (Lond) 244: 209-222

Wilson B, Thompson PM, Hammond PS (1997) Habitat use by bottlenose dolphins: seasonal distribution and stratified movement patterns in the Moray Firth, Scotland. J Appl Ecol 34:1365-1374

Wilson B, Hammond P, Thompson PM (1999) Estimating size and assessing trends in a coastal bottlenose dolphin population. Ecol Appl 9(1):288-300

Würsig B (1978) Occurrence and group organisation of Atlantic bottlenose porpoises (Tursiops truncatus) in an Argentine Bay. Biol Bull 154:348-359

Würsig B, Jefferson TA (1990) Methods of photo-identification for small cetaceans. Rep Int Whaling Comm Spec Issue 12: $43-52$

Würsig B, Würsig M (1979) Behaviour and Ecology of the Bottlenose dolphin, Tursiops truncatus, in the South Atlantic. Fish Bull US 77(2):399-412

Submitted: February 21, 2002; Accepted: August 1, 2002 Proofs received from author(s): November 12, 2002 